\title{
JTRESDA
}

Journal homepage: https://jtresda.ub.ac.id/

\section{Studi Perencanaan Embung Lapangan Jegreg Kecamatan Lengkong Kabupaten Nganjuk Provinsi Jawa Timur}

\author{
Reja Palevi Al Huda ${ }^{*}$, Runi Asmaranto', Very Dermawan' \\ ${ }^{1}$ Jurusan Teknik Pegairan Universitas Brawijaya \\ Jalan Mayjen Haryono No.167, Malang, 65145, Indonesia \\ *korespondensi email: rejapalevi@gmail.com
}

\begin{abstract}
The problem in dry season is about water availability, while during wet season there are often several puddles in an area in Jegreg Village in Nganjuk Regency. This is due to the increasing need of the population which is not in line with the development of water supply facilities and infrastructure. In this study, the authors make an analysis related to this problem, by planning a reservoir that can be used to accommodate water during the rainy season so that can be used to reduce floods. Based on the analysis, the dead storage volume (Sediment) are 9,49 $\mathrm{m}^{3}$, and the effective storage volume are $68,96 \mathrm{~m}^{3}$ and then the total storage volume are $78,45 \mathrm{~m}^{3}$. The height of ponds is 3 meters, with the spillway type is side channel spillway with 0,5 meter of height. In elevation $+40,50$ the width of spillway are 17,15 meters. In stability analysis, the analysis used in the slope stability of the reservoir is the Bishop method with Geostudio2012 application and from the results of the analysis, the safety number meets the requirements. For the analysis of spillway safety against shear and rolling forces, in normal, flood condition, and earthquakes condition, the safety figures meet the requirement.
\end{abstract}

Keywords : Jegreg small dam, overflow, reservoir, stability

Abstrak: Masalah kurangnya air pada saat musim kemarau, sedangkan
ketika musim hujan sering terjadi beberapa genangan pada suatu wilayah
di Desa Jegreg di Kabupaten Nganjuk. Hal ini disebabkan karena semakin
meningkatnya kebutuhan penduduk yang tidak sejalan dengan
pembangunan sarana dan prasarana penyediaan air. Pada studi kali ini
menganalisis terkait dengan masalah tersebut, dengan direncanakan sebuah 
embung sehingga dapat dimanfaatkan guna menampung air pada musim hujan agar dapat dipergunakan untuk memenuhi mereduksi banjir.

Berdasarkan analisis yang telah dilakukan, didapatkan volume tampungan mati $=9,49 \mathrm{~m}^{3}$ volume tampungan efektif embung adalah $68,96 \mathrm{~m}^{3}$, volume total embung $=78,450 \mathrm{~m}^{3}$ dengan tinggi kolam tampungan embung $3 \mathrm{~m}$, untuk bangunan pelimpah menggunakan pelimpah samping dengan tinggi mercu 0,5 m lebar pelimpah 17,15 m terletak pada elevasi +40,50. Dalam analisa stabilitas, analisis yang digunakan dalam stabilitas lereng embung yaitu dengan metode Bishop menggunakan aplikasi Geostudio2012 dan dari hasil analisis mendapatkan angka keamanan memenuhi syarat. Untuk analisis keamanan pelimpah terhadap gaya geser dan gaya guling, dalam kondisi normal dan banjir dan juga gempa mendapatkan angka aman memenuhi syarat.

Kata Kunci: Embung lapangan jegreg, pelimpah, stabilitas, tampungan,

\section{Pendahuluan}

Pada saat musim hujan air banyak meluap sehingga terjadi genangan di beberapa titik Desa Jegreg di Kabupaten Nganjuk yang dapat mengganggu aktifitas sehari-hari warga sekitar, dan pasokan air untuk kebutuhan irigasi terpenuhi sedangkan pada saat musim kemarau pasokan air irigasi untuk khusunya wilayah Desa Jegreg di Kabupaten Nganjuk saat ini dirasakan masih kurang. Untuk lebih meringankan beban warga sekitar terakit produktifitas sektor pertanian dan peternakan, karena kedua bidang usaha tersebut sangat tergantung pada ketersediaan air, maka diperlukan pengelolaan sumber daya air yang ada di daerah tersebut terutama dalam aspek pengusahaan dengan membangun tampungan air yang diutamakan dapat memenuhi kebutuhan air terutama pada saat musim kemara

Hal ini semakin terasa apabila musim kemarau tiba, seperti yang terjadi pada masyarakat yang bekerja sebagai petani sangat membutuhkan pasokan air untuk kebutuhan mengairi lahan sawah khususnya di Desa Jegreg di Kecamatan Lengkong, Kabupaten Nganjuk. Oleh karena itu, diperlukan suatu tampungan air yang dapat menampung air di musim penghujan yang kemudian dimanfaatkan ketika musim kemarau tiba, yaitu dengan dibangunnya embung. Dengan adanya permasalahan tersebut maka diperlukan kajian lebih lanjut untuk merencanakan desain embung. Salah satunya yaitu dengan melakukan studi perencanaan Embung Lapangan Jegreg di Kabupaten Nganjuk Provinsi Jawa Timur.

\section{Bahan dan Metode}

\subsection{Lokasi Studi}


Lokasi studi Embung Lapangan Jegreg terletak di desa Jegrek, Kecematan lengkong, Kabupaten Nganjuk, yang terletak di bagian barat Provinsi Jawa Timur.. Dilihat dari letak geografis Kabupaten Nganjuk berada pada koordinat $111^{\circ} 5^{\prime}-111^{\circ} 13^{\prime}$ BT dan $7^{\circ} 20^{\prime}-7^{\circ} 50^{\prime}$ LS.

\subsection{Bahan}

Data - data yang dibutuhkan untuk melakukan analisis dalam studi kali ini sebagai berikut:

1. Data Curah Hujan Sta. Lengkong tahun 2009 - 2018, guna mendapatkan debit banjir rencana

2. Data Mekanika Tanah dan Geologi, guna mendapatkan stabilitas pada pelimpah dan lereng embung

\subsection{Metode}

\subsubsection{Analisa Hidrologi}

Biasanya analisis tersebut merupakan bagian dari analisis awal dalam desain hidrolik bangunan. Bangunan hidrolik pada bidang teknik irigasi dapat berupa gorong-gorong, bendung, bangunan pelimpah, dan tanggul. Penahan banjir, dll. Proses analisis hidrologi meliputi data curah hujan, intensitas curah hujan, koefisien debit, data resapan air dan pengolahan banjir yang direncanakan.[1]

\subsubsection{Analisa Curah Hujan Rancangan}

Analisa ini dapat digunakan untuk menghitung curah hujan rerata daerah dan maksimum tahunnya. Dalam studi kali ini untuk menghitung curah hujan menggunakan analisa frekuensi Log Pearson III [2].

\subsubsection{Analisis Frekuensi metode Log Pearson III}

Distribusi Log Pearson tipe III banyak digunakan dalam analisis hidrologi, terutama analisis data aliran banjir maksimum dan data aliran minimum [2].

$$
\log \mathrm{Xt}=\log \mathrm{X}_{\text {rerata }}+\mathrm{G} . \mathrm{Sd} \quad \text { Pers. } 1
$$

dengan:

$\mathrm{X}=$ data

$\mathrm{G}=$ koefisien Log Pearson III

$\mathrm{Sd}=$ Standart deviasi data

\subsubsection{Uji Kesusaian Distribusi}

Untuk memperoleh curah hujan dilakukan analisis curah hujan yang direncanakan dan frekuensi distribusi, dan untuk memperoleh curah hujan yang direncanakan atau arus yang direncanakan diperhitungkan dalam perhitungan debit banjir yang direncanakan dilakukan analisis statistik [1].

\subsubsection{Koefisien Pengaliran}


Koefisien pengaliran adalah suatu variabel untuk menentukan besarnya limpasan permukaan tersebut Dengan penentuannya didasarkan pada kondisi Daerah Aliran Sungai dan kondisi hujan yang jatuh di daerah tersebut. Berdasarkan kondisi fisik wilayah dan jenis penggunaan lahan [3].

\subsubsection{Debit Banjir Rancangan Metode Rasional}

Metode Rasional merupakan rumus yang tertua dan yang terkenal di antara rumus-rumus empiris. Metode Rasional dapat digunakan untuk menghitung debit puncak sungai atau saluran namun dengan daerah pengaliran yang terbatas, dijelaskan jika ukuran daerah pengaliran 5000 ha maka koefisien pengaliran (C) bisa dipecah-pecah sesuai tata guna lahan dan luas lahan yang bersangkutan [4].

$$
\mathrm{Q}=\text { 0,278.C. I.A Pers. } 2
$$

Dengan :

$\mathrm{Q}=$ debit puncak yang ditimbulkan oleh hujan dengan intensitas, durasi dan frekuensi tertentu $\left(\mathrm{m}^{3} / \mathrm{dt}\right)$

I $\quad=$ intensitas hujan $(\mathrm{mm} / \mathrm{jam})$

A = luas daerah tangkapan $\left(\mathrm{km}^{2}\right)$

$\mathrm{C} \quad=$ koefisien pengaliran

$0,278=$ faktor konversi

\subsubsection{Analisa Kebutuhan Air}

Guna pemanfaatan Air pada embung rencana ini, air dapat digunakan untuk kebutuhan air irigasi pada wilayah sekitar tampungan pada desa Jegreg [5]

\subsubsection{Analisa Hidrolika}

Penampang Saluran Drainase eksisting berbentuk trapesium berdasarkan debit banjir maksimum yang terjadi. Penampang dihitung dengan persamaan yang dikembangkan oleh manning sebagai berikut[6].

$$
V=\frac{1}{n} \cdot R^{\frac{2}{3}} \cdot S^{\frac{1}{2}} \quad \text { Pers. } 3
$$

Dari persamaan diatas didapat penampang trapesium efisien sebagai berikut

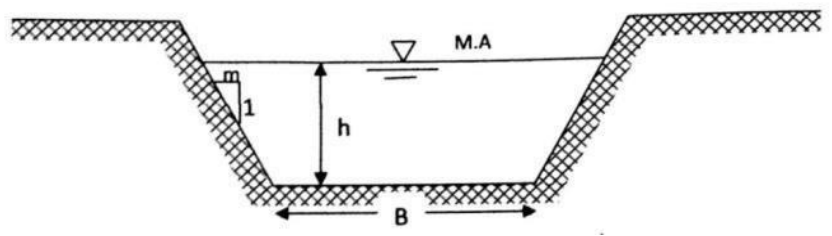

Gambar 1 Penampang Saluran [7] 


$$
\begin{aligned}
\mathrm{Q}=\mathrm{V} . \mathrm{A} & \text { Pers.4 } \\
\mathrm{A}=\left(\mathrm{B}+\mathrm{m}^{*} \mathrm{~h}\right) \mathrm{h} & \text { Pers. 5 } \\
\mathrm{R}=\frac{A}{P} & \text { Pers. 6 } \\
\mathrm{P}=\mathrm{B}+2 \mathrm{~h} \sqrt{ }\left(\mathrm{m}^{\wedge} 2+1\right) & \text { Pers. 7 }
\end{aligned}
$$

Dengan:

$\mathrm{Q}=$ Debit Rancangan $\left(\mathrm{m}^{3} / \mathrm{dt}\right)$

$\mathrm{n}=$ Angka kekasaran

$\mathrm{A}=$ Luas penampang $\left(\mathrm{m}^{2}\right)$

$\mathrm{R}=$ Jari-jari hidrolis $(\mathrm{m})$

$\mathrm{B}=$ Lebar dasar $(\mathrm{m})$

$\mathrm{S}=$ Kemiringan dasar saluran

$\mathrm{m}=$ Kemiringan talud

$\mathrm{P}=$ Keliling penampang $(\mathrm{m})$

\subsubsection{Analisa Pelimpah Samping (Side Weir)}
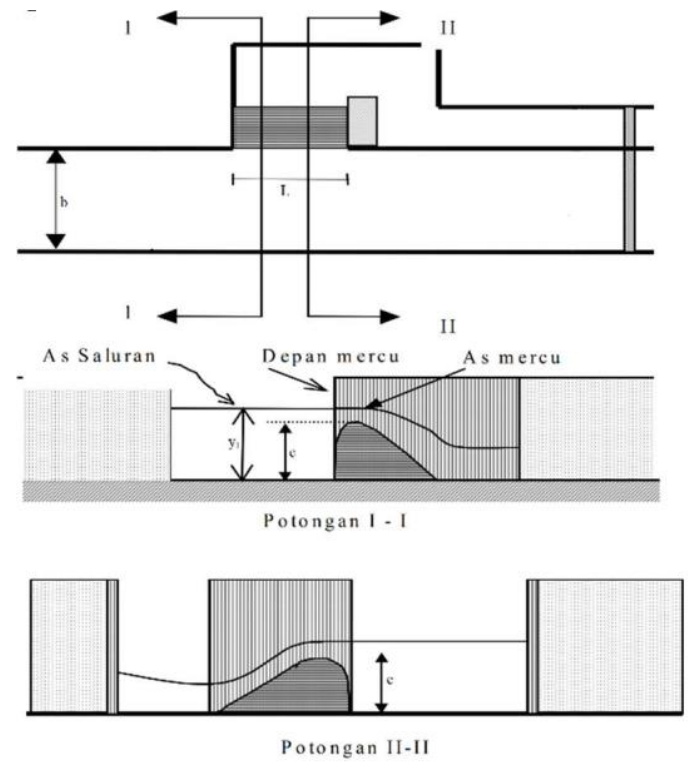

Gambar 2 Denah Pelimpah Samping (Side Weir)

Aliran di pelimpah samping termasuk jenis aliran berubah lambat laun terhadap ruang (spatiall varied flow) dengan penurunan debit yang terjadi sepanjang di saluran utama sepanjang pelimpah. Prinsip energi akan diterapkan secara langsung. [8]

Besarnya debit yang melalui pelimpah dapat dihitung dengan bentuk persamaan

$$
Q=C_{d} * 2 / 3 \sqrt{2 / 3 * g * b * H 1^{1,5}} \quad \text { Pers. } 8
$$

Dengan:

$\mathrm{Cd} \quad=$ koefesien debit 
$\mathrm{b} \quad=$ lebar pelimpah, $(\mathrm{m})$

$\mathrm{H} 1=$ tinggi tekan, $(\mathrm{m})$

Untuk perhitungan koefisien debit dihitung menggunakan rumus De Marchi per pias:[9]

$$
C_{d}=\frac{Q_{p}}{b * \Delta x * \sqrt{2 g(y-c)^{3 / 2}}} \text { Pers. } 9
$$

Untuk Koefisien debit pada depan mercu dan as bendung menggunakan rumus De Marchi per pias:

$$
q_{x}=C_{d} * \Delta x \sqrt{2 g}(\mathrm{~h} 0-\mathrm{c})^{1,5} \quad \text { Pers. } 10
$$

Untuk nilai koefisien debit ditentukan dengan memasukan nilai koefisien debit ke dalam masing-masing segmen sehinga didapat harga $\mathrm{q}_{\mathrm{x}}$.

\subsubsection{Analisa Stabilitas Embung}

Analisa stabilitas embung direncanakan dengan 2 analisis stabilitas dimana analisis stabilitas lereng yang direncanakan adalah untuk memeriksa keamanan lereng terhadap longsor embung lapangan jegreg, kemudian analisis stablitas pada bangunan pelimpah yang berpengaruh terhadap gaya geser guling pada bangunan itu sendiri.[10]

\section{Hasil dan Pembahasan}

\subsection{Analisa Hidrologi}

Untuk analisa hidrologi Embung Lapangan Jegreg yaitu dari stasiun hujan Lengkong tersebut. Penggunaan satu pos dalam analisa hidrologi tersebut mengacu pada buku Pedoman Kriteria Desain Embung Kecil untuk Daerah Semi Kering di Indonesia [6]. Periode observasi 10 tahun dari 2008 hingga 2017.

Tabel 1. Curah Hujan Maksimum

\begin{tabular}{cc}
\hline Tahun & Curah Hujan Maksimum harian tahunan $(\mathrm{mm})$ \\
\hline 2008 & 104 \\
2009 & 108 \\
2010 & 97 \\
2011 & 72 \\
2012 & 110 \\
2013 & 104 \\
2014 & 97 \\
2015 & 72 \\
2016 & 98 \\
2017 & 82 \\
\hline Jumlah & 944 \\
Rerata & 94,40 \\
\hline
\end{tabular}


Tabel 2. Rekapitulasi Uji Chi Square

\begin{tabular}{|c|c|c|c|c|}
\hline No & Distribusi & $\chi_{\mathrm{cr}}^{2}$ & $\chi_{\text {hitung }}^{2}$ & Keterangan \\
\hline 1 & Gumbel & $\begin{array}{l}\alpha=5 \%, 5.991 \\
\alpha=1 \%, 9.210\end{array}$ & 3,00 & Diterima \\
\hline 2 & Normal & $\begin{array}{l}\alpha=5 \%, 5.991 \\
\alpha=1 \%, 9.210\end{array}$ & 1,00 & Diterima \\
\hline 3 & Log Normal & $\begin{array}{l}\alpha=5 \%, 5.991 \\
\alpha=1 \%, 9.210\end{array}$ & 1,00 & Diterima \\
\hline 4 & Log Pearson III & $\begin{array}{l}\alpha=5 \%, 5.991 \\
\alpha=1 \%, 9.210\end{array}$ & 3,00 & Diterima \\
\hline
\end{tabular}

Tabel 3. Rekapitulas Uji Smirnov Kolmogorof

\begin{tabular}{ccccc}
\hline No & Distribusi & D cr & D max & Keterangan \\
\hline 1 & Gumbel & $\alpha=5 \%, 0.409$ & 0,24 & Diterima \\
& $\alpha=1 \%, 0.486$ & & \\
2 & Normal & $\alpha=5 \%, 0.409$ & 0,20 & Diterima \\
& $\alpha=1 \%, 0.486$ & & \\
3 & $\alpha=5 \%, 0.409$ & 0,24 & Diterima \\
4 & Log Normal & $\alpha=1 \%, 0.486$ & & Diterima \\
& & $\alpha=5 \%, 0.409$ & 0,15 & \\
\end{tabular}

Sumber: Analisis Perhitungan

Dari hasil perhitungan pada table diatas dapat disimpulkan bahwa metode tersebut sudah sesuai untuk dilakukan menganlisis hujan rancangan berdasarkan angka simpangan terkecil didapat pada uji dengan metode Log Pearson III

\subsection{Debit Banjir Rancangan}

Untuk menentukan hidrograf satuan daerah pengaliran sungai yang kecil ( $<500$ ha) dan tidak terpasang stasiun AWLR (Automatic Water Level Recorder), dapat digunakan perhitungan metode Rasional Modifikasi. 
Tabel 4. Perhitungan Debit Banjir Metode Rasional

\begin{tabular}{cccccc}
\hline $\begin{array}{c}\text { Kala } \\
\text { Ulang }\end{array}$ & $\begin{array}{c}\text { R-24 Jam } \\
\text { Maks }\end{array}$ & Tc & I & C & Qn \\
$($ tahun $)$ & $(\mathrm{mm})$ & $(\mathrm{jam})$ & $(\mathrm{mm} / \mathrm{jam})$ & & $\left(\mathrm{m}^{3} / \mathrm{dt}\right)$ \\
\hline 1 & 2 & 4 & 5 & 6 & 7 \\
\hline 1.00 & 58,11 & 0,47 & 33,42 & 0,70 & 11,12 \\
1.25 & 82,50 & 0,47 & 47,45 & 0,70 & 15,79 \\
2.00 & 95,67 & 0,47 & 55,03 & 0,70 & 18,31 \\
5.00 & 106,97 & 0,47 & 61,53 & 0,70 & 20,47 \\
10.00 & 111,99 & 0,47 & 64,42 & 0,70 & 21,44 \\
25.00 & 116,61 & 0,47 & 67,07 & 0,70 & 22,32 \\
50.00 & 119,19 & 0,47 & 68,55 & 0,70 & 22,81 \\
100.00 & 121,23 & 0,47 & 69,73 & 0,70 & 23,20 \\
\hline
\end{tabular}

\subsection{Kebutuhan Air Irigasi}

Dalam menentukan jumlah air irigasi yang dibutuhkan dalam penelitian ini, perhitungan pola tanam harus digunakan. Jenis tanaman yang akan digunakan dalam analisis adalah tanaman yang biasa ditanam di masyarakat sekitar yaitu padi dan palawija (Kacang), dengan area yang terlayani sebesar $30 \mathrm{Ha}$

Tabel 5. Kebutuhan Air Irigasi

\begin{tabular}{|c|c|c|c|c|c|c|c|c|c|c|c|c|c|}
\hline \multirow{2}{*}{$\begin{array}{l}\text { Bulan } \\
\text { Periode }\end{array}$} & \multirow{2}{*}{ Satuan } & Okt & \multicolumn{2}{|c|}{ Nov } & \multicolumn{2}{|c|}{ Des } & \multicolumn{2}{|c|}{ Jan } & \multicolumn{2}{|c|}{ Feb } & \multicolumn{2}{|c|}{ Mar } & \multirow{2}{*}{$\begin{array}{c}\text { Apr } \\
\text { I }\end{array}$} \\
\hline & & II & I & II & I & II & I & II & I & II & I & II & \\
\hline $\mathrm{DR}_{\text {Padi }}$ & $\mathrm{lt} / \mathrm{dt} / \mathrm{ha}$ & 0,00 & 0,00 & 1,04 & 0,60 & 1,06 & 1,49 & 0,97 & 0,84 & 0,60 & 0,30 & 0,78 & 0,22 \\
\hline DR $_{\text {Palawija }}$ & $\mathrm{lt} / \mathrm{dt} / \mathrm{ha}$ & 0,08 & & & & & & & & & & & \\
\hline Total & & 0,08 & 0,00 & 1,04 & 0,60 & 1,06 & 1,49 & 0,97 & 0,84 & 0,60 & 0,30 & 0,78 & 0,22 \\
\hline Bulan & & Apr & & & & & & & & & & & Okt \\
\hline Periode & Saluan & II & I & II & I & II & I & II & I & II & I & II & I \\
\hline $\mathrm{DR}_{\text {Padi }}$ & $\mathrm{lt} / \mathrm{dt} / \mathrm{ha}$ & 0,64 & 1,30 & 1,70 & 1,41 & 0,71 & 0,70 & & & & & & \\
\hline DR $_{\text {Palawija }}$ & $1 \mathrm{t} / \mathrm{dt} / \mathrm{ha}$ & & & & & & & 0,48 & 0,87 & 0,99 & 1,06 & 0,74 & 0,56 \\
\hline Total & & 0,64 & 1,30 & 1,70 & 1,41 & 0,71 & 0,70 & 0,48 & 0,87 & 0,99 & 1,06 & 0,74 & 0,56 \\
\hline
\end{tabular}




\subsection{Perencanaan Kolam Tampungan Embung}

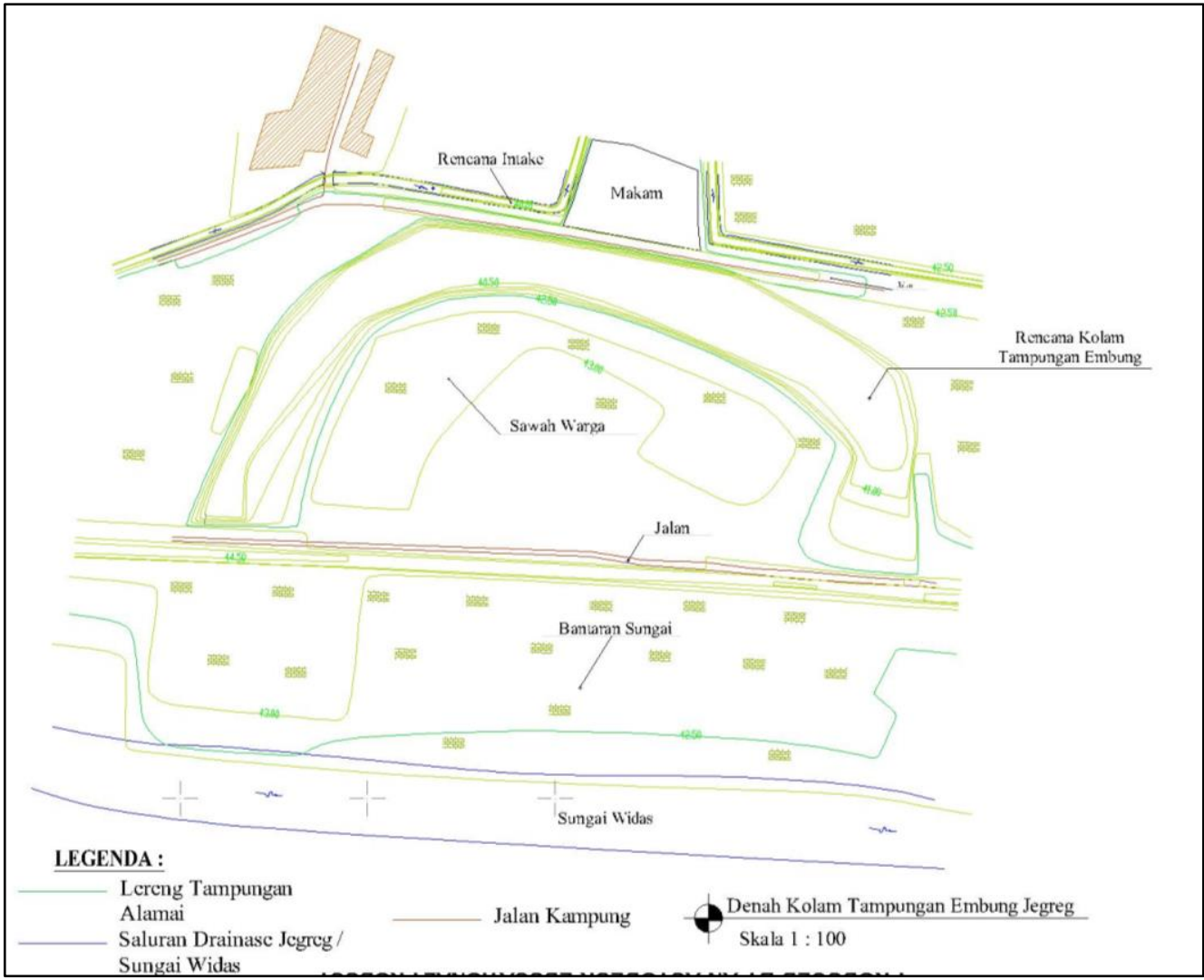

Gambar 3 Denah Tampungan Embung Lapangan Jegreg

Dari Tampungan desain yang diatas didapatkan hasil sebagai berikut:

Volume Tampungaan Embung Lapangan Jegreg

- Saluran Drainase Jegreg mampu mengalirkan air sebesar $8,36 \mathrm{~m}^{3} /$ detik

- Perhitungan Embung Jegreg memotong debit banjir sesuai dengan kapasitas tampungan eksisting saluran drainase jegreg

- $\quad$ Debit puncak yang $>8,36 \mathrm{~m}^{3} / \mathrm{dt}$ akan ditampung pada Embung Jegreg, dan debit yang < $8,36 \mathrm{~m}^{3} / \mathrm{dt}$ dialirkan melalui saluran drainase Jegreg menuju K. Widas

- $\quad$ Elevasi dasar tampungan kolam $+37,00 \mathrm{~m}$

- $\quad$ Elevasi tampungan maksimum berada $+40,00 \mathrm{~m}$

- Debit inflow pada tampungan embung sebesar 5124,87 $\mathrm{m}^{3}$

- Selisih antara inflow dan outflow kumulatif adalah merupakan volume yang ditampung oleh Embung Jegreg dan dialirkan/ dibuang menuju K. Widas.

- Bilamana elevasi muka air K. Widas lebih rendah dari muka air embung maka mengalirkan air dapat dilakukan secara gravitasi.

- Kapasitas tampungan Embung Jegreg pada elevasi +40 dengan kedalaman air $=3,0 \mathrm{~m}$, luas genangan $=27.98 \mathrm{~m}^{2} ;$ volume $=68.956 \mathrm{~m}^{3}$ 
Untuk mengalihkan debit pada saluran drainase jergreg yang berlebih, sehingga harus ada bangunan pengendali untuk membagi arus banjir guna mereduksi genangan pada sekitar saluran drainase jegreg. Pada studi kali ini bangunan kontrol yang digunakan merupakan bangunan "pelimpah samping (SideWeir)" tanpa pintu. Guna mendapatkan lebar pelimpah samping diperlukan besaran nilai debit banjir yang akan dialihkan aliran air melalui pelimpah tersebut. Analisa perhitungan digunakan dengan metode numeris yang diperkenalkan oleh $D e$ Marchi.

Tabel 6 Hasil-Analisis Bangunan Pelimpah Samping (De Marchi)

\begin{tabular}{ccccccccccc}
\hline $\begin{array}{c}\Delta \mathbf{x} \\
\mathrm{m}\end{array}$ & $\begin{array}{c}\mathbf{Q}_{\mathbf{0}} \\
\mathrm{m}^{3} / \mathrm{dt}\end{array}$ & $\begin{array}{c}\mathbf{H}_{\mathbf{0}} \\
\mathrm{m}\end{array}$ & $\begin{array}{c}\mathbf{h}_{\mathbf{0}} \\
\mathbf{M}\end{array}$ & $\begin{array}{c}\mathbf{h}_{\mathbf{0}}-\mathbf{c} \\
\mathbf{M}\end{array}$ & $\begin{array}{c}\mathbf{q}_{\mathbf{x}} \\
\mathrm{m}^{3} / \mathrm{dt}\end{array}$ & $\begin{array}{c}\mathbf{Q}_{\mathbf{0}}+\mathbf{q}_{\mathbf{x}} \\
\mathrm{m}^{3} / \mathrm{dt}\end{array}$ & $\begin{array}{c}\mathbf{A}_{\mathbf{x}} \\
\mathrm{m}^{2}\end{array}$ & $\begin{array}{c}\mathbf{V}_{\mathbf{x}} \\
\mathrm{m} / \mathrm{dt}\end{array}$ & $\begin{array}{c}\mathbf{h}_{\mathbf{x}} \\
\mathrm{m}\end{array}$ & $\begin{array}{c}\mathbf{\Sigma} \mathbf{\Delta \mathbf { x }} \\
\mathrm{m}\end{array}$ \\
\hline$[1]$ & {$[2]$} & {$[3]$} & {$[4]$} & {$[5]$} & {$[6]$} & {$[7]$} & {$[8]$} & {$[9]$} & {$[10]$} & {$[11]$} \\
\hline 5,72 & 8,36 & 1,32 & 1,17 & 0,67 & 5,27 & 13,64 & 8,05 & 1,69 & 1,17 & 5,72 \\
5,72 & 13,64 & 1,32 & 1,17 & 0,67 & 5,29 & 18,92 & 8,06 & 2,35 & 1,03 & 11,43 \\
5,72 & 18,92 & 1,31 & 1,03 & 0,53 & 3,76 & 22,69 & 6,99 & 3,25 & 0,78 & 17,15 \\
\hline
\end{tabular}

Sumber: Analisis Perhitungan, 2020

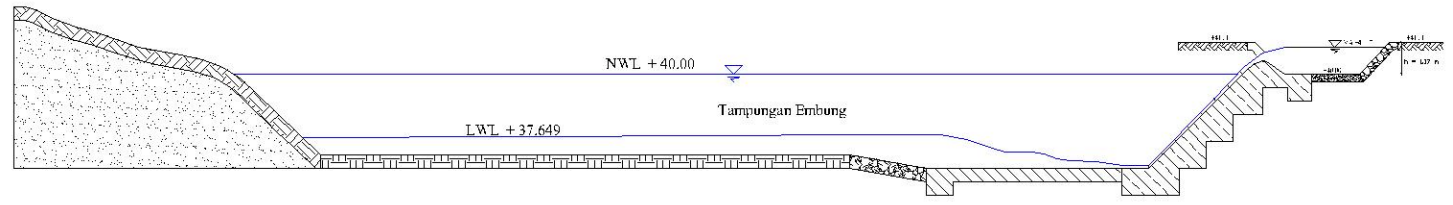

Detail Mercu Pclimpah Samping dan Tampungan Embung Jcgreg

SKALA 1:100

Gambar 4 Layout Pelimpah Samping

\subsection{Analisa Stabilitas Bangunan}

Pada studi kali ini menggunakan analisa stabilitas lereng dan stablitas pada pelimpah dengan beberapa kondisi, yakni:

Tabel 7. Hasil Analisa Stabilitas Pelimpah

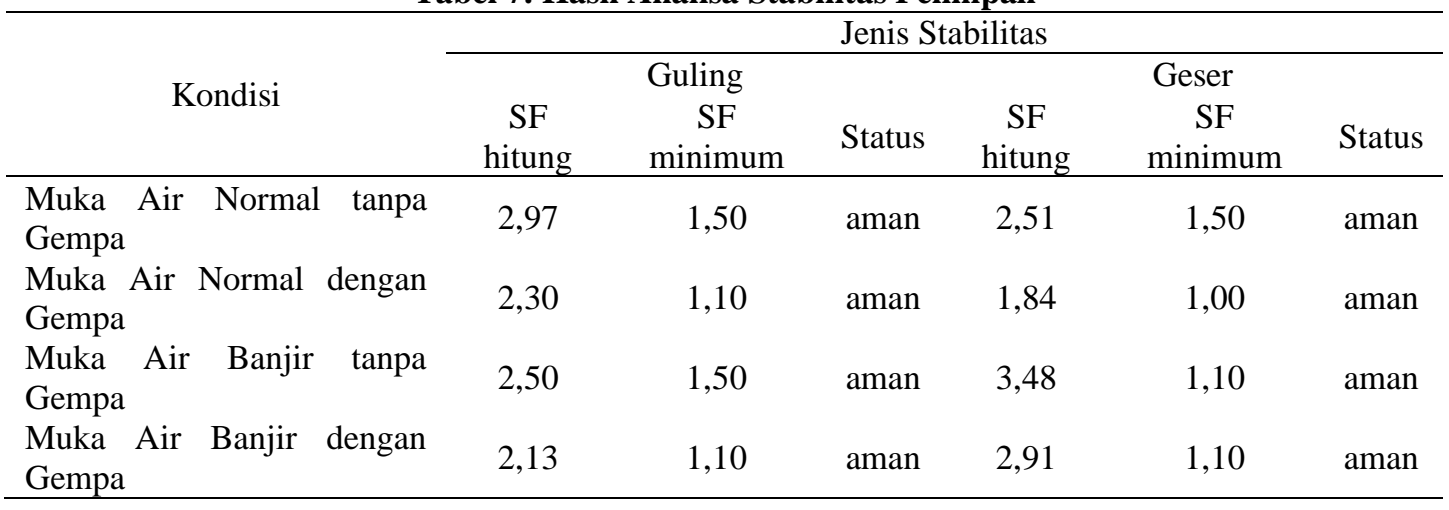


Tabel 8. Hasil Analisa Stabilitas Lereng Embung

\begin{tabular}{ccccccc}
\hline Kondisi & $\begin{array}{c}\text { SF } \\
\text { hitung }\end{array}$ & $\begin{array}{c}\text { Kanan } \\
\text { SF } \\
\text { minimum }\end{array}$ & Status & $\begin{array}{c}\text { SF } \\
\text { hitung }\end{array}$ & $\begin{array}{c}\text { KF } \\
\text { minimum }\end{array}$ & Status \\
\hline Waduk Kosong tanpa & 2,70 & 1,50 & aman & 1,64 & 1,50 & aman \\
$\begin{array}{c}\text { Gempa } \\
\text { Waduk Kosong dengan }\end{array}$ & 1,91 & 1,10 & aman & 1,31 & 1,10 & aman \\
$\begin{array}{c}\text { Gempa } \\
\text { Muka Air Normal } \\
\text { tanpa Gempa }\end{array}$ & 2,78 & 1,50 & aman & 1,62 & 1,50 & aman \\
$\begin{array}{c}\text { Muka Air Normal } \\
\text { dengan Gempa }\end{array}$ & 1,64 & 1,10 & aman & 1,22 & 1,10 & aman \\
\hline
\end{tabular}

Sumber: Analisis Perhitungan, 2020

\section{Kesimpulan}

Dari hasil analisis yang telah dilakukan, maka diperoleh beberapa output penting terkait dengan perencanaan Embung Lapangan Jegreg, sebagai beriku:

- Genangan Air yang tereduksi dari saluran drainase jegreg sebesear $14,33 \mathrm{~m}^{3} / \mathrm{dt}$ dengan volume $827,11 \mathrm{~m}^{3}$.

- Kebutuhan air irigasi pada daerah sekitar hanya sebesar 30 ha

- Tampungan efektif Embung Jegreg sebesar volume $68.956 \mathrm{~m} 3$ dan terletak pada elevasi + $40.00 \mathrm{~m}$ dpl. Bangunan masukan guna pengatur tinggi muka air yang bertujuan melimpaskan debit dari saluran Drainase ke embung menggunakan pelimpah samping/sideweir dengan lebar $12.608 \mathrm{~m}$, jika elevasi muka air K. Widas lebih rendah dari muka air embung maka mengalirkan air dapat dilakukan secara gravitasi

- Dimensi embung dan pelimpah yang aman, serta tampungan embung yang sesuai untuk mereduksi banjir masyarakat kecamatan Lengkong Desa Jegreg. Berikut merupakan beberapa poin ringkasan studi perencanaan didapatkan Elevasi puncak pelimpah $=+40,50$ $\mathrm{m}$ dpl, Elevasi FWL $=+41,61 \mathrm{~m} \mathrm{dpl}$, Elevasi $\mathrm{NWL}=+40.00 \mathrm{~m} \mathrm{dpl}$, Elevasi $\mathrm{LWL}=+$ 37,649 $\mathrm{m} \mathrm{dpl}$, Tipe pelimpah = Side Weir, Debit Side Weir $=14,33 \mathrm{~m}^{3} / \mathrm{dt}$, Lebar pelimpah= $17,15 \mathrm{~m}$, Tipe mercu pelimpah= ogee tipe II, Panjang peredam energi $=7,50 \mathrm{~m}$, Elevasi peredam energi $=+36.50 \mathrm{~m} \mathrm{dpl}$, Tipe peredam energi $=$ USBR tipe I, Panjang Escape Channel $=2.86 \mathrm{~m}$

- Dari hasil perhitungan stabilitas pada lereng embung dan stabilitas pelimpah didapatkan hasil. Pada Stabilitas Pelimpah untuk Kondisi Normal tanpa gempa dapat dinyatakan aman dalam bangunan dengan nilai SF Guling $=2,97$ dan SF Geser $=2,51$. Pada Stabilitas Pelimpah untuk Kondisi Normal dengan gempa dapat dinyatakan aman dalam bangunan dengan nilai SF Guling $=2,30$ dan SF Geser $=1,84$. Pada Stabilitas Pelimpah untuk Kondisi Banjir tanpa gempa dapat dinyatakan aman dalam bangunan dengan nilai SF Guling $=2,50$ dan SF Geser $=3,48$. Pada Stabilitas Pelimpah untuk Kondisi Banjir dengan gempa dapat dinyatakan aman dalam bangunan dengan nilai SF Guling = 2,13 dan SF Geser = 2,97. Pada Stabilitas Lereng dengan Kondisi Embung Kosong tanpa gempa Sebelah Kanan 2,70 dan sebelah Kiri 1,64 dapat dinyatakan aman. Pada Stabilitas Lereng dengan Kondisi Embung Kosong dengan gempa Sebelah Kanan 1,91 dan sebelah Kiri 1,31dapat dinyatakan aman. Pada Stabilitas Lereng dengan Kondisi Embung Muka Air Normal tanpa gempa Sebelah Kanan 2,78 dan sebelah Kiri 1,62 dapat dinyatakan aman. Pada Stabilitas Lereng dengan 
Kondisi Embung Muka Air Normal dengan gempa Sebelah Kanan 1,64 dan sebelah Kiri 1,22 dapat dinyatakan aman.

\section{Daftar Pustaka}

[1] Harto, Sri.1993. Analisis Hidrologi. Jakarta: PT Gramedia Pustaka Umum

[2] Soemarto, CD. (1987). Hidrologi Teknik. Surabaya: Usaha Nasional.

[3] Sosrodarsono, Suyono. (1977). Bendungan Type Urugan. Jakarta : Pradnya Paramita.

[4] Limantara, Lily Montarcih. (2010). Hidrologi Terapan. Malang : CV. Citra Malang.

[5] Departemen Pekerjaan Umum (2013). Standar Perencanaan Irigasi Kriteria. Perencanaan Bagian Jaringan Irigasi KP-01. Jakarta: Kemetrian Pekerjaan Umum

[6] Chow. (1997). Hidraulika Saluran Terbuka. Erlangga. Bandung.

[7] Priyantoro, D. 2018. Hidrolika Saluran Terbuka. Buku Ajar. Tidak dipublikasikan. Malang: Universitas Brawijaya.

[8] Departemen Pekerjaan Umum (2013). Standar Perencanaan Irigasi, Kriteria Perencanaan Bagian Bangunan Utama KP-04. Jakarta : Kementrian Pekerjaan Umum Direktorat Jendral Sumber Saya Air Direktorat Irigasi dan Rawa

[9] Soekarno, I. 2006. Pengaruh Arah Sayap Pelimpah Samping Dan Kedalaman Aliran Terhadap Koefisien Debit. Journal Civil. CED, Vol. 8, No. 1, 8-14.

[10] Soedarmo, Djatmiko. 1997. Mekanika Tanah 2. Malang : Kanisius. 